\title{
STRUCTURALIST AND CULTURAL DOMINATION THEORIES MEET TITLE VII: SOME CONTEMPORARY INFLUENCES
}

\section{Martha Chamallas*}

I often have trouble predicting how Title VII cases will come out. Like so many fields of law, Title VII law is dynamic, unsettled, and hotly contested. Particularly because the advance sheets seem to contain at least two divergent lines of cases - conservative and progressive - it is useful to speak in the plural when describing the visions of equality and discrimination embedded in the contemporary caselaw. In many cases, equality seems narrowly conceived. To avoid charges of discrimination, employers need only provide formal access to jobs and occupations, freedom from overt bias stemming from race or gender prejudice, and an opportunity to assimilate into the existing structures and processes of the workplace. A smaller group of cases, however, implicitly embraces broader visions of equality. Courts sometimes question the legitimacy of established patterns of racial and gender stratification. They then reach beyond issues of access to uncover the links between access and the working culture and environment.

This contest over the meaning of workplace equality is most visible in the scholarly trends that have developed over the thirty years since the passage of Title VII. In critical legal scholarship and in the social sciences, structuralist and cultural domination theories have emerged to challenge more conventional notions of equality centering on individual motivation and choice. These two newer approaches, I believe, already have had a discernible influence in the courts. Although such progressive incursions into Title VII have been limited and sporadic, they are enough to allow me to

* Professor of Law, University of Pittsburgh. B.A. 1971, Tufts; J.D. 1975, Louisiana State University. - Ed. Many thanks to my colleagues at the University of Iowa Women's Studies Program - Rusty Barcelo, Susan Birrell, Carolyn Dyer, Barbara Eckstein, Sally Kenney, Sue Lafky, Teresa Mangum, Geeta Patel, Nancy Reincke, and Carolyn Sachs - for participating in a workshop on this piece. I am also grateful to Kathryn Abrams, Nancy Hauserman, Carolyn Jones, Peter Shane, and Lea VanderVelde for their comments on an earlier version of this essay, and to Nancy Reincke, Mary Tabor, Mark Briggs, Shauna Russell Shields, and Liza Diaz for their excellent research assistance. 
speculate on the direction Title VII might take if these two nondominant visions gained more prominence in the law.

This essay first looks at three important theoretical approaches - motivational, ${ }^{1}$ structural, ${ }^{2}$ and cultural ${ }^{3}$ - that mark the scholarly discourses on workplace equality since 1965 . The motivational or individual choice theory is well established and has dominated legal discourse throughout this period. I concentrate in this essay on the other two visions, dating structuralist accounts from the mid1970s and cultural domination theories from the mid-1980s.

I then sketch the impact of these new visions on Title VII doctrine - noting cases in which plaintiffs have relied on structural or cultural accounts of discrimination to help articulate their theories of liability. The structuralist influence has surfaced in sexual stereotyping and sexual harassment cases in which expert testimony has been used to explain the distinctive problems women face in intensively male-dominated workplaces. ${ }^{4}$ The impact of cultural domination theories can now be seen in a few sexual and racial harassment cases that challenge the choice of perspective from which the law evaluates a charge of offensive or hostile working environment. 5 These structuralist and cultural domination influences are still at the margins of Title VII and have yet to be adequately theorized in legal scholarship. The nondominant visions have had little or no impact in several core areas of the law, including challenges to wage structures and occupational segregation, disputes about affirmative action, the scope of available remedies, and litigation over oppressive workplace rules and conditions other than violence or harassment.

This essay begins to explore the implications of structuralist and cultural domination theory for Title VII doctrine. In the 1990s, the most pressing issue is no longer formal access; at least some members of traditionally excluded groups have successfully integrated virtually every high-status occupation. The demographics of most organizations remain stratified, however, with disproportionate numbers of white men continuing to occupy the highest ranks, accompanied typically by token numbers of minorities and women. ${ }^{6}$

1. See infra Part I.

2. See infra Part II.

3. See infra Part III.

4. See infra Part IV.

5. See infra Part V.

6. See Reynolds Farley \& Walter R. Allen, The Color Line and the Qualtiy OF LIFE IN AMERICA 271-73 (1987) (showing that in 1980 about $12 \%$ of black men compared with $25 \%$ of white men had jobs in the top two occupational categories; $50 \%$ of black men 
Moreover, most women continue to work in low-paying, low-mobility, largely segregated jobs. ${ }^{7}$ Research of the last two decades supports the view that differences in the motivations or choices of individuals cannot adequately explain such persistent patterns of tokenism and segregation. Legal doctrine that does not address the impact of workplace structures, processes, and cultural norms on the lives of employees is incapable of responding to many of the "second generation" issues arising in Title VII disputes.

\section{Motivational Explanations in Social Science and Legal Discourse}

When Title VII was first enacted and throughout the 1960s, research in the social sciences often focused on identifying psychological characteristics of women and racial minorities that would explain why these groups did not achieve "success" in the workplace. In its most simplified form, the motivational line of scholarship asked what there was about outsiders - what were the traits, qualities, and dispositions - that prevented them from attaining positions of power and status. This inquiry directed attention to those who had been excluded and away from the actions of decisionmakers. Posing the question in this way was apt to elicit a victim-blaming response that held the outsider responsible for his or her own predicament.

A classic example of motivational research that was used to explain women's lack of representation in professional or high-status careers is Matina Horner's work on women's "fear of success" in the late $1960 \mathrm{~s}^{8}$ Horner argued that highly educated women often

compared with $25 \%$ of white men worked at less-skilled, blue-collar jobs); BARBARA $F$. Reskin \& Patricia A. Roos, Job Queues, Gender Queues: Explaining Women's INROADS INTO MALE OCcupations 5-6 (1990) ("Blacks, whether male or female, are less likely than whites to command well-paid managerial or professional jobs.").

7. Women's Bureau, U.S. Dept. OF LaBor, 20 Leading Occupations of Employed WOMEN, 1990 AnNual Averages (Mar. 1991). Almost half of all women are employed in occupations that are at least $80 \%$ female; these women include, for example, librarians, health technicians, secretaries and typists, data-entry keyers, nurses, bank tellers and bookkeepers, telephone operators, sewers and stitchers, child-care workers, and dental assistants. WOMEN's WORK, MEN's WORK 7 (Barbara F. Reskin \& Heidi I. Hartmann eds., 1986); see also Mary Ann Mason, Beyond Equal Opportunity: A New Vision for Women Workers, 6 Notre Dame J.L. Ethics \& Pub. Poly. 393, 397 n.18 (1992) (reporting that according to Department of Commerce data published in $1986,50.7 \%$ of all women work in only 19 of the 503 occupational categories, all except 3 of the 19 occupations are $60 \%$ or more female, and 15 of the 19 predominantly female occupations pay in the bottom half of the 421 ranked earnings); Deborah L. Rhode, Occupational Inequality, 1988 Duke L.J. 1207, 1208-12 (discussing statistical patterns of segregation and wage inequity).

8. Horner's research was first publicized in 1969 in an article in Psychology Today summarizing the results of her dissertation project on women's fear of success. See Matina S. Horner, A Bright Woman Is Caught in a Double Bind, Psychol. TODAY, Nov. 1969, at 36 
undermine their own prospects for achievement in the outside world because of internal conflicts about their potential success. According to Horner, women's ambivalence about success arises both from their fears that intellectual achievement would result in a loss of femininity and from a deep-seated, unconscious association of success with loneliness, societal rejection, and despair. ${ }^{9}$ The construct of the fear of success was hypothesized as a static property, acquired in early childhood and activated later to stifle career goals. ${ }^{10}$ Horner envisioned the fear of success as something that most women brought with them into college classrooms or the workplace and that could not readily be changed by the actions of employers or other institutional decisionmakers. The construct was particularly well suited to explain the phenomenon of tokenism, because only exceptional women who did not possess the fear of success could be expected to integrate male domains. The focus on the inadequacy of the excluded group, moreover, meant that the criteria and measures of success would not be subjected to close scrutiny.

The motivational explanation for women's exclusion from maledominated jobs struck a responsive chord in the 1960s, a time when highly educated women often found themselves working as homemakers or secretaries. Horner's theory was taken up by research$e^{2}{ }^{11}$ and the popular media ${ }^{12}$ to a degree that is rare for academic work. It has been described, for example, as "one of the most extensively studied psychological theories involving women's behav-

[hereinafter Horner, A Bright Woman]. She discusses her research more thoroughly in Matina S. Horner, Toward an Understanding of Achievement-Related Conflicts in Women, 28 J. SOC. Issues 157 (1972).

9. Horner, A Bright Woman, supra note 8, at 36-38.

10. Id. at 38.

11. Horner's methodology and interpretation of data were scrutinized, criticized, and used as the basis for further studies. See, e.g., John Condry \& Sharon Dyer, Fear of Success: Attribution of Cause to the Victim, 32 J. Soc. Issues 63 (1976); Kimberley R. Gelbort \& Jane L. Winer, Fear of Success and Fear of Failure: A Multitrait-Multimethod Validation Study, $4 \mathrm{~J}$. Personality \& Soc. Psychol. 1009 (1985); Nancy M. Henley, Psychology and Gender, 11 Signs 101 (1985); Michele A. Paludi, Psychometric Properties and Underlying Assumptions of Four Objective Measures of Fear of Success, 10 Sex Roles 765 (1984); David Tresemer, Do Women Fear Success?, 1 Signs 863 (1976); Peter J. Weston \& Martha T. Mednick, Race, Social Class and the Motive to Avoid Success in Women, 1 J. Cross-Cultural Psychol. 283 (1970).

12. Colette Dowling's 1981 bestseller capitalized on the popularity of Horner's thesis and used the fear of success to support the notion that women have a hidden fear of independence. See Colette Dowling, The Cinderella Complex: Women's Hidden Fear of INDEPENDENCE 170-79 (1981). 
ior"13 and as a "proven personality trait . .. [that] has worked its way into standard sources of gospel."14

Perhaps the most important feature of Horner's line of motivational research was its focus on the psychology of individual women, locating the origin of the problem in the early socialization of women. The implication of Horner's research was that success is within the reach of individual women, if only their psychological makeup would allow them to attain it. Further, because patterns of women's psychological development are unlikely to change quickly, it was reasonable to expect sexual integration of jobs to proceed very slowly. The practical implications of the motivational theory posed no substantial threat to existing organizations or professions. Congruent with Horner's own career as president of Radcliffe College, ${ }^{15}$ the best antidote for fear of success promised to be the counseling of individual women at elite schools to help them reevaluate their career aspirations.

The motivational orientation continues to influence contemporary scholarship on workplace equality and probably dominates the discourse in the popular culture. It is most prominent in discussions about women and work, but it also surfaces in analyses of the situation of racial minorities. Randall Kennedy's analysis of the demographics of the legal academy, for example, relies in part on a fear-of-failure theory to explain the small percentage of black academics, especially at elite institutions. ${ }^{16}$ Reminiscent of Horner, Kennedy speculates that such fear may cause black scholars "to engage in various strategies of avoidance: for example, exempting themselves from the risks of failure by refusing to compete on the same terms as whites or refraining from investing themselves wholeheartedly in their careers."17

In its contemporary version in the mass media, the motivational explanation for women's occupational status has tended to shift from fear of success and fear of loss of femininity to an emphasis on women's choice to subordinate their careers to accommodate fam-

13. Mary R. Walsh, Do Women Fear Stuccess?, in The Psychology of Women 165, 165 (Mary R. Walsh ed., 1987).

14. Paludi, supra note 11 , at 766.

15. Horner was appointed president of Radcliffe College in 1972 and served in that capacity for 17 years. See Vivian Gornick, Why Radcliffe women are afraid of success, N.Y. TIMEs, Jan. 14, 1973, \& 6 (Magazine), at 10; Zoë Ingalls, New President Challenged to Define Radcliffe's 'Fugitive Nature,' CHRON. Higher Educ., Feb. 14, 1990, at A3.

16. See Randall L. Kennedy, Racial Critiques of Legal Academia, 102 HARv. L. Rev. 1745 (1989).

17. Id. at 1769. 
ily obligations. Tokenism and segregation is now typically explained by women's lack of geographic mobility, their need to interrupt careers to have children, and their desire to spend less time at work - the "mommy track."18 Like the earlier motivational explanations, however, the central feature of these "family conflict" theories of women's occupational status was to locate the principal cause of tokenism and segregation in the choices that individual women make and to imply that women's psychology is highly relevant to those choices.

Motivational explanations have also been prominent in the rhetoric and reasoning of courts deciding Title VII cases, exerting a significant influence on how courts view patterns of segregation and tokenism. The most well-established theory of liability - the theory of intentional disparate treatment - is premised on the motivation of individuals. Under the disparate treatment theory, courts conceptualize discrimination as the outcome of discrete, biased acts of individuals. Statistical proof of patterns of segregation and exclusion do not as such constitute violations of the law for these courts. Rather, they require courts to interpret the origins of those patterns. The critical question is whether to draw from these patterns an inference of discriminatory motivation on the part of the employer or to infer that the patterns result from choices made by members of the underrepresented groups themselves.

Vicki Schultz's pathbreaking scholarship on the judicial treatment of the "lack-of-interest" defense in Title VII cases'19 demonstrates the hold that motivational explanations have had on the thinking of the courts. Schultz contends that the courts' willingness

18. Felice Schwartz's views, for example, bear a strong resemblance to Horner's. See Felice N. Schwartz, Management Women and the New Facts of Life, HARv. Bus. REv., Jan.Feb. 1989, at 65. Schwartz hypothesizes that women in management positions fall into two categories - career-primary women and career-and-family women - not unlike the women with and without fear of success. Id. at 68 . For the more traditional women - that is, those who are career-and-family minded - Schwartz argues that management should create a more relaxed, flexible, and lower-paid working schedule to accommodate their family conficts. Id. at 70-72. Male managers in Schwartz's schema are presumed to be career-primary in their motivation. Id. at 67. Schwartz's views became popularized as advocating the "mommy track." See Felice N. Schwartz, The "Mommy Track" Isn't Anti-Woman, N.Y. TIMEs, Mar. 8, 1989, at A18; Tamar Lewin, "Mommy Career Track" Sets Off a Furor, N.Y. Times, Mar. 8, 1989, at A18; see also Suzannah B. Wilson, Note, Eliminating Sex Discrimination in the Legal Profession: The Keys to Widespread Social Reform, 67 IND. L.J. 817, 843-47 \& nn. 193-220 (1992) (collecting references).

19. Vicki Schultz, Telling Stories About Women and Work: Judicial Interpretations of Sex Segregation in the Workplace in Title VII Cases Raising the Lack of Interest Argument, 103 Harv. L. Rev. 1749 (1990); Vicki Schultz \& Stephen Petterson, Race, Gender, Work, and Choice: An Empirical Study of the Lack of Interest Defense in Title VII Cases Challenging Job Segregation, 59 U. CHI. L. REv. 1073 (1993). 
to accept a lack-of-interest argument in the controversial case of EEOC v. Sears, Roebuck \& Co. ${ }^{20}$ was not unusual.

Sears involved a challenge to workplace segregation. The claim was that Sears had discriminated against women by maintaining a gender-stratified sales force, with men dominating the higher-paid, commissioned sales jobs and women relegated to the lower-paid, noncommissioned sales work. ${ }^{21}$ The court rejected the EEOC's contention that the workforce statistics were highly probative of sex discrimination. Sears persuaded the court that the pattern could be attributed to women's own preferences for more noncompetitive work in what was characterized as a feminine, friendly environment. 22

To support her view that the ruling in Sears was not atypical, Schultz analyzed sex discrimination cases decided between 1972 and 1989 that raised the lack-of-interest defense. She found that in almost half of the cases, courts concluded that sex segregation was attributable to women's own work preferences. ${ }^{23}$ As Schultz explains it, the dominant narrative that emerges from these cases is of a world in which employees form their preferences for certain types of jobs and occupations before they enter the labor force. ${ }^{24}$ The conservative version of the story posits that, because of biology or sex-role socialization, women tend to prefer female or feminine jobs and simply are not interested in nontraditional work, despite its greater economic rewards. ${ }^{25}$ The liberal version of the story resists assigning an automatic preference for certain types of jobs based on an employee's gender, ${ }^{26}$ but like the conservative version, the liberal account accepts the causal connection between the preferences of individual employees and the resulting gender composition of jobs and occupations. ${ }^{27}$ What is missing from both versions is the role played by workplace structures, processes, and ideologies in shaping or constituting workers' preferences. Schultz theorizes that both liberal and conservative courts tend to operate within a

20. 628 F. Supp. 1264 (N.D. III. 1986), affd., 839 F.2d 302 (7th Cir. 1988). For a discussion of the case, see Ruth Milkman, Women's History and the Sears Case, 12 FEMINIST STud. 375 (1986).

21. 628 F. Supp. at 1278.

22. 628 F. Supp. at 1305-15, 1326-27.

23. Schultz, supra note 19 , at 1777 .

24. See id. at 1800.

25. Id. at 1800-05.

26. Id. at 1806-14.

27. Id. at 1807-08. 
motivational framework when they approach the critical issue of sexual segregation in the workplace. ${ }^{28}$

In race discrimination cases raising the lack-of-interest defense, Schultz has again documented the continuing importance of motivational explanations in shaping Title VII doctrine. The pattern Schultz uncovers in race discrimination cases differs from that in sex discrimination cases. Between 1967 and 1977, the ten-year period immediately following enactment of Title VII, the courts most often rejected the lack-of-interest defense and seemed to assume that racial segregation was a product of labor market inequalities. ${ }^{29}$ This more plaintiff-oriented phase of Title VII litigation ended in the late 1970s. In the more recent era, Schultz has found that motivational explanations are an important influence in racial segregation cases. Since 1977 , courts have been more apt to attribute racial segregation to the choices of minority workers. ${ }^{30}$ The motivational account as it is expressed in racial segregation cases posits that minorities choose low-paying jobs because they "lack the initiative to pursue better alternatives." 31 Courts trace the paradox of African Americans' choosing to work at low-paying, low-mobility jobs to internal, psychological responses such as a different cultural attitude toward work, lack of discipline, or lack of commitment.

Although the script differs, the sex and race narratives share a basic motivational framework. In each, there is a search for difference, focusing on some intrinsic quality of the applicant or employee, whether it is styled "motivation," "interest," or "preference." This difference is then used to explain why members of the disadvantaged group do not have the same measure of success as the privileged group. There may be disputes about whether the difference really exists, but courts rarely ask whether the difference justifies imposing a disadvantage on the employee or whether the difference is partly attributable to the employer. In the motivational account, responsibility lies with the individual worker; the employer is required only to measure or judge each worker evenhandedly using conventional standards.

As I have described it, the motivational orientation is so deeply embedded in discussions of workplace equality and discrimination that it is often invisible. As with most dominant paradigms, the

28. Id. at 1800 . 75.

29. Schultz \& Petterson, supra note 19, at 1098; see also Schultz, supra note 19, at 1771-

30. Schultz \& Petterson, supra note 19 , at 1098.

31. Id. at 1080 . 
motivational orientation gains its power from being accepted implicitly, rarely being subjected to close scrutiny.

\section{Structuralist Theory and Workplace EQuality}

By the mid-1970s, the psychological model of Horner and others was challenged by research that tended to blame "the system" rather than individuals and sought explanations for racial and sexual imbalances in the structures of institutions. One of the most prominent structuralist scholars of this era was Rosabeth Moss Kanter. ${ }^{32}$ Her famous ethnology of a large firm - Men and Women of the Corporation ${ }^{33}$ - focused on the dynamics of segregation and tokenism as they affect women in the corporation. Kanter's structuralism started from the premise that "the job makes the person," 34 such that, for example, employees with little opportunity to advance will respond by lowering their aspirations and by seeking satisfaction outside the job. The structuralist orientation also located discrimination outside the minds of individuals who make discrete decisions. Kanter reframed and enlarged the concept of discrimination to make it a byproduct of structure, "a consequence of organizational pressures as much as individual prejudice."3s

Kanter described her brand of structuralism as an "intermediate level analysis" 36 that, at the time Kanter wrote, was lacking in much of the research about women and work. Until the 1970s, theorists had concentrated either on "highly macroscopic" trends, like tracking labor force participation rates of women, or, like Horner, on "very microscopic" discussions about women's individual psychology or socialization. ${ }^{37}$ Acknowledging an intellectual debt to femi-

32. Kanter was the first woman to receive a Ph.D. in social psychology from Michigan and later taught in Yale's sociology department. She was a diversity consultant to businesses and an editor of the Harvard Business Review. See Susanne Lawrence, Rosabeth Moss Kanter: Professor of Entrepreneurship and Innovation, Harvard Business School, 18 PERSON. NEL MGMT., Sept. 1986, at 22; Susan McHenry, Rosabeth Moss Kanter, Ms., Jan. 1985, at 62; Joan Vennochi, What They Don't Teach You at the Harvard Business School, Workina WOMAN, Feb. 1993, at 52.

33. Rosabeth M. Kanter, Men and Women of the Corporation (1977). Kanter's influence has been profound in the social sciences. Even contemporary critics of Kanter use her scholarship as the reference point for their empirical studies. See, e.g., Robin J. Ely, Organizational Demographics and Women's Gender Identity at Work (John F. Kennedy School of Government, Harvard University, Faculty Research Working Paper Series, 1993); Janice D. Yoder, Rethinking Tokenism: Looking Beyond Numbers, 5 Gender \& Socy. 178 (1991).

34. KANTER, supra note 33, at 9.

35. Id.

36. Id. at xiii.

37. Id. 
nism, ${ }^{38}$ Kanter sought to explain how organizational structures constrain and empower individuals to act. Much of her work was devoted to showing the organizational or political aspect of what had formerly been accepted as personal or private. The structuralist account of the workplace is that of a highly politicized site where informal encounters often have more importance than formal meetings - where success on the job is measured more by peer acceptance than by competence in performing the tasks found in the formal job description. ${ }^{39}$

Numbers are very important in structuralist analyses of the workplace. A major theme of Kanter's work is the self-perpetuating nature of tokenism..$^{40}$ Kanter investigated what she called the "skewed" group, in which there is a large predominance of men roughly eighty-five percent or more. ${ }^{41}$ She believed that the men in skewed groups typically control the work culture, such that it is fair to describe the men as "dominants" and the women as "tokens." 42 Stereotyping is also likely to flourish in skewed settings that lack a critical mass of women. ${ }^{43}$

This focus on the skewed group is historically significant; in the middle to late 1970 s, women had begun to enter nontraditional jobs. Many women who were not in women's fields, such as nursing or teaching, were likely to find themselves in such skewed settings. The tipping point for Kanter is located somewhere between fifteen and thirty-five percent, in groups she described as "tilted." 44 In these tilted groups, the hypothesis is that tokens will become "minorities" and will be able to form coalitions and engage in other effective strategies to influence the culture of the organization. ${ }^{45}$ Although Kanter regarded her theory as applicable to any minority group in the workplace, ${ }^{46}$ it most directly addressed the predicament of women - and perhaps only white women - because women are the only minority group large enough to reach the percentages Kanter suggested for moving beyond token status.

38. Id.

39. For a contemporary application of structuralist theory to the dynamics of tokenism in academia, see Paula Dressel et al., The Dynamics of Homosocial Reproduction in Academic Institutions, 2 AM. U. J. GENDER \& L. 37 (1994).

40. See KANTER, supra note 33, at 210, 241-42, 249.

41. Id. at 208.

42. Id.

43. Id. at 230 .

44. Id. at 209.

45. Id.

46. See id. at 207. 
In the structuralist account, the demographics of the workplace signal not only which groups exercise control but also how employees from nondominant groups are likely to be regarded and evaluated. Stereotyping is a central dynamic encompassing more than a set of overbroad generalizations attached to certain groups. One very important theme in Kanter's work, for example, is her explication of the social construction of tokens in the workplace. ${ }^{47} \mathrm{Her}$ research contested the notion that stereotypes of a group would break down in the face of the counterexample of a real person who did not fit the mold. Instead, in a skewed group it often is easier to make the person fit the generalization about the group than to change the generalization. ${ }^{48}$ Professional women in the corporation are individually noticed; people know their names and watch their actions. But because women are known primarily because of their sex, they are not known as individuals. The phenomenon of selective perception means that women are noticed and rated on a scale for women only, with focus on their style of dress, their appearance, their bodies, their social graces, and other nonability traits. ${ }^{49}$

Selective perception combined with typecasting can distort everyday encounters with women at work. The behavior of token women is apt to be assimilated and reduced to patterns associated with women outside the workplace. Women are trapped into roles: they can be likened to a mother, a little sister (or pet), or a sexual object (seductress, mistress), or cast as a militant (iron maiden, virgin aunt). Each of these role traps is an obstacle to women's advancement. Mothers might be appreciated for their emotional work, but emotional work is not highly valued in the corporate arena. Little sisters are not taken seriously enough to be considered leaders. Because men tend to compete for the attention of a sexual object, her presence is thought to cause divisions. The militant is looked upon with suspicion from a distance and left to manage on her own. ${ }^{50}$

The structuralist analysis of typecasting emphasizes its dynamic, interactive nature. There is a "feedback loop" between the dominant group's perception of the token and the token's behavior. It is often easier for token women to gain an "instant identity" by conforming to one of the preexisting stereotypes. ${ }^{51}$ Even those who

47. See id. at $230-36$.

48. Id. at $230-31$.

49. Id. at 216-17.

50. Id at 233-37.

51. Id. at 211. 
resist the feminine stereotypes can be placed into a position of continual alertness to their own behavior, to make sure they do not unwittingly exhibit stereotypically feminine traits. ${ }^{52}$ Either strategy results in a measure of self-distortion, with the token holding back whatever fits or does not fit into the preconceived roles. In this way, stereotyping and typecasting - processes over which the employer has some measure of control - actually shape the behavior and identity of employees.

The implication of the structuralist position is that "organizations - not people - [have] to change"53 to break down the patterns of tokenism and segregation. Kanter's prescription for change was batch or cluster hiring: hire more than one woman at a time and concentrate them, rather than scatter them, throughout the organization. ${ }^{54}$ This "critical mass" strategy was thought to maximize women's potential to influence the culture in their specific working groups. The strategy also implied that if women are involved in making decisions about women, that will make a difference. Stereotyping is most prevalent when male-only committees sit in judgment of women.

The structuralist orientation represented a clear alternative to the motivational orientation that had dominated the discourse prior to the 1970 s. From the lens of organizational structure, it was possible to reconsider prior research - like that of Matina Horner - in a less victim-blaming fashion, while offering more interventionist strategies for change. For example, Kanter reinterpreted Horner's research to reveal the token woman's fear of visibility, rather than a more generalized fear of success among women. 55 Kanter's research had shown that men resent the visibility of a token woman and often retaliate if they think that a woman is trading on her visibility to get ahead. When tokens become "stars," they risk intense negative reaction from their professional peers and are likely to be abandoned the first time they encounter problems. ${ }^{56} \mathrm{~A}$ common response among token women is to try to limit their visibility, to avoid taking risks, and to play a behind-the-scenes role. In the structuralist account, the fear of success was reframed to be situational and amenable to change; it was assumed that women's fears

52. Id. at 237.

53. Id. at 261 .

54. Id. at 282.

55. See id. at 221; see also Rosabeth M. Kanter, Reflections of Women and the Legal Profession: A Sociological Perspective, 1 HARv. Women's L.J. 1, 13 (1978).

56. KANTER, supra note 33, at 218. 
would lessen as the risk of retaliation against successful women lessened.

Perhaps the most important contribution of the structuralist approach is its ability to explain difference without naturalizing it. Kanter, for example, challenged the notion that gender was special by offering a more gender-neutral theory premised on relative numbers. One of her objectives was to demonstrate that roles and situations, rather than "verifiable 'sex differences," "57 are better predictors of behavior and performance at work. Disputing the existence of essential sex differences, however, does not mean that gender in the workplace is irrelevant. Instead, the structuralist account explains how even workers with the same job title can have dramatically different work experiences; how, for example, token women perform their jobs under different "public and symbolic" conditions than their male peers. ${ }^{58}$

Because the structuralist account emphasizes the internal dynamics of the organizations, it is not grounded in the common assumption that women's maternal and sexual roles determine their career aspirations and the way they function at work. Theories such as Horner's trade on women's "natural role" as mothers and imply that women are psychologically comfortable only in domestic situations. The structuralist severing of the family-work axis means that subordination in the family need not inevitably be replicated in the workplace.

As an intellectual force, structuralism found its way into legal discourse through Catharine MacKinnon's work on sexual harassment. Her influential text, Sexual Harassment of Working Women, ${ }^{59}$ published in 1979, reframed sexual harassment as a structural abuse that was a byproduct of women's inferior position in the workplace. MacKinnon's analysis deprivatized the injury of sexual harassment. She sought to dispel the commonly held view that onthe-job harassment is a personal matter produced by sexual attraction or office flirtation.

Connecting sex segregation with harassment, MacKinnon argued that sexual harassment was facilitated by two structural forces: horizontal segregation, which meant that vast numbers of women were employed in pink-collar, feminized jobs; ${ }^{60}$ and tokenism, which severely limited the number of women working in male-

57. Id. at xiii.

58. Id. at 212.

59. Catharine A. Mackinnon, Sexual Harassment of Working Women (1979).

60. Id. at 9. 
defined jobs.61 For MacKinnon, the capacity to be sexually harassed was an informal job qualification for women in feminized jobs. Drawing on Kanter and other sociologists, MacKinnon described secretarial work as "sex-defined" work in which secretaries are required to be deferential, pleasing, supportive, wifelike, receptive, and willing to project sexual availability, even if they have no desire for sexual attention from men at work. ${ }^{62}$ Particularly because women in female-dominated jobs were most likely to have male supervisors, ${ }^{63}$ the structure of the workplace replicated and reinforced a gender hierarchy that placed women in the double bind of needing to appear compliant while successfully resisting sexual overtures. For token women in male-dominated jobs, MacKinnon theorized that they were singled out for harassment because they were highly visible, marked by their sex, and an easy target for male co-workers who resented the invasion of their territory. ${ }^{64}$

Most recently, Vicki Schultz and Elvia Arriola have examined how, in the last two decades, sexual harassment has limited the number of women in blue-collar jobs and other nontraditional occupations. Arriola's study of pioneer female construction workers in New York City, for example, demonstrated how virulent harassment, often combined with employers' failure to train and co-workers' sabotage of women's work performance, can make it difficult for even highly motivated women to remain in hostile environments. ${ }^{65}$ Using a version of the structuralist feedback loop, Schultz explicated the connection between on-the-job harassment and women's aspirations for nonsegregated work. ${ }^{66}$ She asserted that women are reluctant to apply for masculine jobs because they realize that "behind the symbolism of masculinized job descriptions lies a very real force: the power of men to harass, belittle, ostracize, dismiss, marginalize, discard, and just plain hurt them as workers." 67

Structuralist scholars portray segregation and tokenism as resilient forces, not capable of breaking down simply because some indi-

61. Id.

62. See id. at 18-23.

63. MacKinnon describes this structural feature as "vertical stratification." Id. at 12-13.

64. See id. at 40.

65. Elvia R. Arriola, "What's the Big Deal?" Women in the New York City Construction Industry and Sexual Harassment Law, 1970-1985, 22 Colum. HuM. RTS. L. REv. 21 (1990).

66. Schultz, supra note 19, at 1833-39.

67. Id. at 1838. 
viduals change their attitudes or aspirations. But the scholarship of Kanter, MacKinnon, Schultz, and other structuralists also has an activist quality; it is designed to show that the status quo is not inevitable and to suggest what measures can be taken to bring about change.

From an antidiscrimination law perspective, moreover, structuralism is an optimistic theory because it opens up possibilities for effective legal intervention. Under Title VII, the principal defendant is the organization; employers, not individual supervisors or coemployees, are typically held liable. ${ }^{68}$ Courts are thus called upon to decide whether it is fair to hold the employer responsible and whether a remedy directed against the employer will actually work to increase opportunities for protected groups. The structuralist account provides a solid rationale for holding employers accountable because it traces the origin of segregative patterns to the demographics of the workplace and to the opportunity structures within which employees make choices. An employer's hiring decisions, for example, take on an interactive quality; when an employer hires a particular applicant, the employer does not simply recognize the applicant's abilities or talents but, over time, actively shapes the new employee's behavior and contributes to the employee's success or failure. In the structuralist account, the individual employee is an active agent who makes strategic choices within constraints and enabling structures provided by the employer. The employer and the employee each share responsibility for the results.

The activist stance and the optimism of several of the structural scholars, however, were hard to sustain in light of the dramatic turn to the right in U.S. politics in the 1980s. The political climate meant that the prospects for significant structural changes were remote. The problems persisted while the enthusiasm for affirmative action and restructuring of the workplace abated. During this period, professional women complained of their inability to break through the "glass ceiling,"69 an invisible but impenetrable barrier that prevented women from attaining those positions that they were close

68. Title VII imposes liability on an "employer," defined as an entity employing 15 or more persons and including any "agent" of the employer. 42 U.S.C. \& $2000 \mathrm{e}$ (b) (1988). Supervisors who qualify as "agents" may also be individually liable for Title VII violations in certain situations. See Barbara Lindemann \& David D. Kadue, Sexual Harassment IN EMPLOYMENT LAW 515-21 (1992).

69. See Patricia M. Wald, Breaking the Glass Ceiling, 16 Hum. RTs. 40 (1989). The Civil Rights Act of 1991 established a Glass Ceiling Commission to explore artificial barriers to women's career advancement. Glass Ceiling Act of 1991, Pub. L. No. 102-166, tit. II, 105 Stat. 1081-87 (codified at 42 U.S.C. $\$ 2000$ e (Supp. III 1991)). 
enough to see. Women in clerical positions described their lack of mobility as the "sticky floor" syndrome.70 Susan Faludi's book Backlash, ${ }^{71}$ which elaborately documented the resistance in the 1980s to women's initiatives for independence begun in the 1970s, generated an intense response from women. Most recently, Ellis Cose's The Rage of a Privileged Class ${ }^{72}$ struck a responsive chord among African-American professionals. Cose detailed how at a time when most white Americans believe that racism has ended or has greatly subsided, patterns of racial segregation and tokenism continue to limit opportunities for even the most elite minorities. With this growing realization of the tenacity of workplace inequality, a more somber scholarship emphasizing ideological barriers developed in the mid-1980s - a scholarship that supplements, complements, and to a degree challenges the work done by the structuralists.

\section{Cultural Domination Theory and the Containment OF EQUALITY}

The newest orientation to address workplace equality issues the cultural domination approach - has been most thoroughly developed by critical race and feminist legal scholars. As embodied in the work of Derrick Bell, ${ }^{73}$ cultural domination theory posits that dominant groups will find various ways to maintain their position in society. A major theme of this scholarship is that oppression can be reproduced and progress is not inevitable. ${ }^{74}$ Cultural domination theorists are alert to the prospect that racial and gender hierarchies may remain intact, even if specific structures or forms of oppression change. In the cultural domination account, even policies such as affirmative action, designed to integrate the workplace, can backfire if they fail to address "culturally ingrained responses" that deny

70. See Barbara P. Noble, At Work: And Now the 'Sticky Floor,' N.Y. Times, Nov. 22, 1992, $\$ 3$ (Business), at 23 (discussing an empirical study by Prof. Catherine White Berheide).

71. Susan Faludi, Backlash: The Undeclared War Against American Women (1991).

72. Elus Cose, The Rage of a Privileged Class (1993).

73. His two major books are Derrick Bell, ANd We Are Not SAved: The Elusive Quest for Racial Justice (1987) [hereinafter Bell, ANd We Are Not Saved, and Derrick Bell, faces at the Bottom of the Well: The Permanence of Racism (1992).

74. For a description of some of the major features of contemporary critical race scholarship, see Charles R. Lawrence III, et al., Introduction to MARI J. MATSUDA ET AL., WordS That Wound: Critical Race Theory, Assaultive Speech, and the First AmendMENT 1, 6-7 (1993). 
legitimacy to any situation in which white men are not in a "clearly dominant role."75

Cultural domination theorists argue that discrimination operates at the unconscious level, such that even members of the minority groups do not escape the effects of the dominant ideology. In this vein, for example, Charles Lawrence has described racism as a system of thought and action that is

much more complex than either the conscious conspiracy of a power elite or the simple delusion of a few ignorant bigots. It is a part of our common historical experience and, therefore, a part of our culture. It arises from the assumptions we have learned to make about the world, ourselves, and others as well as from the patterns of our fundamental social activities. ${ }^{76}$

Derrick Bell embraced this cultural definition of racism in his influential "Chronicle of the DeVine Gift," concerning "the unspoken limits on affirmative action."77 Bell's chronicle uncovers a peculiarly contemporary form of tokenism - a phenomenon I call "containment." In the tale, Geneva Crenshaw is the only black professor at a major law school. She explains that she had become increasingly overloaded with doing the extra work that comes with being a token - counseling students, serving on endless committees, being called on to help when there is a racial crisis. She had watched as the faculty rejected subsequent minority candidates as unqualified, even some with credentials better than her own. The DeVine gift came in the form of superqualified minority candidates who magically became available to fill the curricular and other needs of the school. ${ }^{78}$

By the time there were six minority faculty, diverse in ethnicity and gender, the law school seemed poised to go beyond tokenism. The moment of insight occurred, however, when the faculty refused to hire the exceptionally talented Seventh Candidate. The Dean explained that just as Howard University wished to stay a black institution, the law school wished to maintain its image as a white

75. See Bell, ANd We Are Not Saved, supra note 73, at 157.

76. Charles R. Lawrence III, The Id, the Ego, and Equal Protection: Reckoning with Unconscious Racism, 39 Stan. L. Rev. 317, 330 (1987); see also Bell, AND We ARE Not SAVED, supra note 73 , at $4-5$ (quoting the same passage).

77. The chronicle was first published in Derrick Bell, The Supreme Court, 1984 TermForeword: The Civil Rights Chronicles, 99 HARv. L. REv. 4, $39-57$ (1985), under the title "The Chronicle of the DeVine Gift." The chronicle is included in BELL, AND WE ARE NOT SAVED, supra note 73, at 140-61, as a chapter entitled "The Unspoken Limit on Affirmative Action."

78. Bell, ANd We Are Not SAVed, supra note 73, at 142. 
school and could not afford to go higher than twenty-five percent in representation of racial minorities.79

Bell intentionally leaves the moral of the chronicle open-ended. I read it as embodying a theory of tokenism that places special emphasis on cultural domination. Racial and gender diversity are contained before they have the effect of changing the culture of the law school. Bell locates the source of the resistance to diversity whether to the first or to the seventh candidate - in the unconscious desire to preserve the white racial identity of the school. ${ }^{80}$ The preference for white domination is the unspoken limit on affirmative action. The somber message implicit in cultural domination theory is that institutions will resist change simply because they cannot believe that high quality is consistent with diversity. The cultural explanation is alert to numbers, particularly as it focuses on the question of why the dominant group feels threatened and resists the introduction of a critical mass of minorities in the workplace. But unlike Kanter, Bell does not assume that the problem lies mainly in the numbers. Hiring more women or more minorities may not be enough. In the cultural account, the relationship between numbers and ideological impact is not symmetrical. There is no guarantee that stereotypes and negative images about others will disappear once their representation reaches beyond a certain point.

Under Bell's cultural domination theory, institutions follow a policy of containment - both ideologically and in terms of numbers - by adopting culturally slanted notions of merit and, when necessary, by changing the definition of merit to assure that the white racial status of the institution is maintained. ${ }^{81}$ Cultural domination theorists tend to regard "merit" as a moving target. When there is integration in one sector - for example, law school admissions - it is likely that another credential that far fewer minorities or women possess - for example, a Ph.D. in economics or a Rhodes scholarship - will emerge as the new indicator of excellence. This shift rarely results from a conscious conspiracy among those in power to select the standard with the most exclusionary impact. It is rather the cultural association of whiteness (or maleness) with merit and value that leads people to believe that exclusionary sites are the most prestigious. Cultural domination theory, for example, explains the phenomenon of job shifting - the lowering in prestige when a particular job or occupation shifts over time

79. Id. at 144.

80. See id. at 158.

81. See id. at 145 . 
from male-dominated to female-dominated, such as the job of secretary or bank teller. ${ }^{82}$ It also supports a major tenet of the comparable worth campaign: that men's work is valued more highly than women's work, regardless of the inherent tasks of the job. ${ }^{83}$

The importance placed on ideological containment in the cultural domination analysis helps to explain the contemporary predicament of institutions that seem to incorporate women and other outsiders without changing the values of the institution. A dramatic example of such resistance to change in academia can be seen in Carolyn Heilbrun's public struggle with Columbia University. ${ }^{84}$ Heilbrun is an esteemed writer who pioneered the field of women's biography and autobiography. ${ }^{85}$ Although she received many of the formal markers of prestige - she held an endowed chair in the English department and was past president of the Modern Language Association - Heilbrun resigned her academic post in protest, claiming that Columbia denied her the informal power that usually accompanies high rank. According to Heilbrun, Columbia's hostility to feminism meant that Heilbrun's sponsorship of graduate students and junior faculty had little effect. Her outspokenness on women's issues caused her colleagues to shun her and discount the importance of her work. At that time, Columbia's English department was not wholly lacking in diversity, with seven of the thirtyone tenured faculty being women. The condition that precipitated Heilbrun's protest was not simply the scarcity of women but the containment of feminism. Heilbrun's activism challenged the identity of the institution - an identity that Heilbrun claimed was fundamentally male.

82. See MACKInNon, supra note 59, at 11-12; Reskin \& Roos, supra note 6, at 11-15; Ruth G. Blumrosen, Wage Discrimination, Job Segregation, and Title VII of the Civil Rights Act of 1964, 12 U. Mich. J.L. REF. 397, 415-20 (1979); Martha Chamallas, Exploring the "Entire Spectrum" of Disparate Treatment Under Title VII: Rules Governing Predominately Female Jobs, 1984 U. ILL. L. REv. 1, 25-27.

83. For a sample of the voluminous literature on comparable worth, see LINDA M. BLUM, Between Feminism and Labor: The Significance of the Comparable Worth MoveMENT (1991); COMPARABle WORTH: New DiRections for Research (Heidi I. Hartmann ed., 1985).

84. The account of Heilbrun's protest is taken from Anne Matthews, Rage in a Tenured Position, N.Y. Times, Nov. 8, 1992, § 6 (Magazine), at 47.

85. Heilbrun's books include: Carolyn G. Heilbrun, Hamlet's Mother and Other Women (1990), Carolyn G. Heilbrun, Reinventing Womanhood (1979), Carolyn G. Heilbrun, Toward a Recognition of Androgyny (1973), and Carolyn G. Heilbrun, Writing A Woman's Life (1989). To many, Heilbrun is best known as Amanda Cross, a prolific mystery writer who created the character of detective Kate Fansler. See, e.g., Amanda Cross, Death in a Tenured Position (1981); Amanda Cross, The Players Come Again (1990). 
Perhaps because the cultural account of workplace discrimination emphasizes ideology and deemphasizes numbers, it has been more attentive to discrimination against women of color and other people who are the minorities within minority groups. By the late 1980s, black feminist scholars ${ }^{86}$ and lesbian theorists ${ }^{87}$ had developed a strong critique of progressive discourses, citing their failure to take account of diversity within minority groups. Institutions were charged with showcasing black men and white women as visible tokens, ignoring women of color and members of other ethnic and racial groups. Kimberlé Crenshaw's theory of intersectionality, for example, asserted that the most privileged within a minority group - heterosexual white women, minority men - were the most likely to benefit from legal intervention and voluntary affirmative action. ${ }^{88}$ Patricia Cain forcefully argued that the agenda of contemporary feminist legal scholars often excluded lesbians and their experiences and concerns. ${ }^{89}$ The compound and distinctive nature of discrimination faced by minority women has recently been confirmed by a comprehensive empirical study of tenure-track law faculty by Deborah Merritt and Barbara Reskin. ${ }^{\circ 0}$ Their study concludes that in the legal academic job market, minority women fare less well than minority men, despite comparable credentials and experience.

Although individual scholars tend to emphasize one or perhaps two dimensions of personal identity, ${ }^{91}$ cultural domination theory

86. Some influential early texts include: All the Women Are White, All the Blacks Are Men, But Some of Us Are Brave (Gloria T. Hull et al. eds., 1982); ANGela Y. Davis, Women, Race \& Class (1981); Paula Giddings, When and Where I Enter: The Impact of Black Women on Race and Sex in America (1984); Home Girls: A Black Feminist ANTHOlogy (Barbara Smith ed., 1983); Bell hooks, Ain't I A Woman: BLACK WOMEN AND Feminism (1981); and Audre LORde, Sister OUTSider (1984). For an analysis of this body of scholarship, see Patricia. Hill Collins, Black Feminist Thought (1990).

87. Some widely cited texts are: Sarah L. Hoagland, Lesbian Ethics: Toward New Value (1988); Marilyn Frye, $A$ Lesbian Perspective on Women's Studies, in Lesbian StudIES: Present and Future 194 (Margaret Cruikshank ed., 1982); and Adrienne Rich, Compulsory Heterosexuality and Lesbian Existence, 5 Signs 631 (1980).

88. See Kimberlé Crenshaw, Demarginalizing the Intersection of Race and Sex: A Black Feminist Critique of Antidiscrimination Doctrine, Feminist Theory and Antiracist Policies, 1989 U. ChI. Legal F. 139, 152; Kimberlé Crenshaw, Race, Gender, and Sexual Harassment, 65 S. Cal. L. Rev. 1467, 1467-68 (1992).

89. See Patricia A. Cain, Feminist Jurisprudence: Grounding the Theories, 4 Berkeley WOMEN's L.J. 191 (1989).

90. See Deborah J. Merritt \& Barbara F. Reskin, The Double Minority: Empirical Evidence of a Double Standard in Law School Hiring of Minority Women, 65 S. CAL. L. REv. 2299, 2301 (1992).

91. It is extremely difficult to pay equal attention to race, ethnicity, sex, class, sexual orientation, disability, and age. Even writers committed to investigating multiple oppression often limit their focus. For example, Bell's cultural domination theory seems to have been 
has the potential to respond to multiple differences. The inclusive quality of cultural domination theory comes from the premise that at some point all nondominant social groups will be contained. In contrast to structural accounts like Kanter's, cultural domination theorists do not assume that the predicament of all social groups is fundamentally the same. They tend, instead, to acknowledge that the specific impact of exclusionary mechanisms on different social groups will inevitably differ, with some groups suffering more than others. The common ground is the oppressive nature of the dominant ideology - the myths that support domination of the many by the few.

The cultural domination orientation goes beyond structuralist approaches, such as Kanter's, in seeing the social constructedness of the identity, not only of the outsiders or tokens in the workplace, but of the dominant group itself. Bell's chronicles, for example, are a device to allow us to see that the dominant group constructs myths about race and then is able to impose these illusions by political, legal, and other collective actions. This focus on the dominants' construction of their own cultural identity expands the inquiry into the relationship between knowledge and power to include all the actors in the workplace.

An important feature of the cultural domination orientation is the assumption that there are few or no limits on the ability of the dominant group to maintain its position. If reality depends on the version of reality that gets accepted, only what is unimaginable for those in power is off limits. This chimerical quality of culture is disconcerting in that it means that the Big Lie can be accepted as truth. It also means that progress can be undone and that there is no assurance that race or sex discrimination will subside, rather than increase. The narrative of gradual progress implicit in many of the structural accounts is absent in cultural domination theory.

Cultural domination theorists, however, are not relentlessly pessimistic. The chimerical quality of culture also means that there is

constructed with the specific situation of African-American men in mind. Bell regards - "credentialism" - the emphasis on graduation from a prestigious law school, grades in law school, law review membership, and judicial clerkships - as the chief cause of tokenism on the Harvard law faculty and has urged that more emphasis be placed on a candidate's career as a distinguished teacher or practitioner. See Letter of Complaint from Derrick Bell, Weld Professor of Law, Harvard Law School, to Michael L. Williams, Assistant Secretary for Civil Rights, Office of the U.S. Department of Education (Mar. 1, 1992) (on file with author). The same forms of credentialism may not pose barriers for white women who face other exclusionary mechanisms, such as assumptions about their lack of geographic mobility or conflicting family ties. See Deborah J. Merritt et al., Family, Place and Career: The Gender Paradox in Law School Hiring, 1993 Wis. L. Rev. 395, 396. 
nothing natural or inevitable about cultural beliefs and patterns. Even the most settled meanings can be changed, and alternative perspectives are possible. This is eloquently illustrated by Patricia Williams's response to Bell's chronicles. Williams invokes the illusional quality of culture to help her understand her situation as a token black law professor:

I comforted myself that my sense of alienation and now-heightened visibility were not inherencies of my blackness and my femaleness but an uncomfortable atmospheric condition afflicting everyone.

... I know that my feeling of exaggerated visibility and invisibility are the product of my not being part of the larger cultural picture. I know too that the larger cultural picture is an illusion, albeit a powerful one, concocted from a perceptual consensus to which I am not a party; and that while these perceptions operate as dictators of the truth, they are after all merely perceptions. ${ }^{92}$

To a greater extent than structuralists, cultural domination theorists stress the importance of perspective and regard knowledge as situated, acknowledging the possibility of multiple truths and realities. In this respect, the cultural domination orientation, as I describe it, shares a common theme with feminist jurisprudence. The emphasis on perspective and the corresponding critique of objectivity and universal truth have been the hallmark of much of the feminist legal scholarship of the past decade. ${ }^{93}$ Unmasking the hidden male viewpoint underlying seemingly neutral laws and policies has become a central method of feminists who claim that the law is unresponsive to women's needs and experiences. Feminists embracing various schools of thought - whether labeled as liberal, ${ }^{94}$ radical, ${ }^{95}$ or relational ${ }^{96}$ - agree that women's difference from men has been used to justify disadvantage and that the concept of difference itself needs to be unpacked and examined.

The feminist investigation of difference has yielded two related insights: that the neutral concept of difference tends to obscure the

92. Patricia Williams, A Brief Comment, with Footnotes, on the Civil Rights Chronicles, HaRv. BlackLetter J., Spring 1986, at 79, 81 n.3.

93. For an excellent overview of the major themes and debates within feminist legal theory, see Anne C. Dailey, Feminism's Return to Liberalism, 102 YALE L.J. 1265 (1993) (reviewing Feminist Legal TheORY (Katherine T. Bartlett \& Rosanne Kennedy eds., 1991)).

94. See, e.g., Wendy W. Williams, Equality's Riddle: Pregnancy and the Equal Treatment/ Special Treatment Debate, in Feminist Legal Theory: Foundations 128, 140 (D. Keily Weisberg ed., 1993) (critiquing the male standard in the Supreme Court's treatment of pregnancy leave).

95. See, e.g., Catharine MacKinnon, Difference and Dominance: On Sex Discrimination, in FEMINISM UNMODIFIED 32, 34 (1987) (critiquing the male standard in equal protection cases).

96. See, e.g., Carol Gilligan, In a Different Voice: Psychological Theory and WOMEN'S DEVELOPMENT 1 (1982) (criticizing the male standard in psychological research). 
power of those who are able to label others as different, and that even an acknowledged difference, without more, is no justification for unfavorable treatment. Martha Minow's scholarship ${ }^{97}$ exemplifies this critical approach to difference and to the connection between difference and domination. Minow argues for a relational concept of difference that challenges the prevailing view of difference as some intrinsic and objective quality of certain groups..$^{98}$ In her work, Minow seeks to dislodge the oppressive meaning of difference as deviation from the norm and to question the reference point by which the comparison of difference is made. ${ }^{99}$ By showing the social constructedness of the concept of difference, Minow's theory contrasts sharply with motivational research that is premised on the search for intrinsic difference. Her focus on conceptual categories and ways of thinking also differs from the more materialist orientation of structuralists. ${ }^{100}$ Like Bell's, Minow's critique of difference locates discrimination in hard-to-displace habits of mind, unlikely to be undone by changes in the organizational chart or even the demographics of the organization.

The strategies linked to the cultural domination orientation are less obvious than those implied by the motivational or structural orientation. The importance placed on ideological containment assumes that piecemeal reforms, such as hiring a few more minorities or installing an affirmative action officer, will be co-opted by the dominant culture unless accompanied by a shift in the meaning of blackness or femaleness in the broader society. Rather than focusing solely on the internal dynamics of the organization, cultural domination theory suggests that contradictions and myths in the larger culture need to be addressed and explored. The awareness that short-term victories can turn out to be long-term losses means that winning a grievance or a lawsuit may not always be the best strategy. The situation may instead call for consciousness-raising programs or cultural criticism through the mass media. Cultural domination theorists are more likely to believe that only sustained political pressure, rather than organizational self-interest, can be re-

97. The fullest elaboration of Minow's approach to difference is found in MarTHA Minow, Making All the Difference (1990). Two important earlier articles addressing the same theme are Martha Minow, The Supreme Court, 1986 Term-Forward: Justice Engendered, 101 Harv. L. Rev. 10 (1987), and Martha Minow, When Difference Has Its Home, 22 Harv. C.R.-C.L. L. Rev. 111 (1987).

98. Minow, supra note 97, at 52-53.

99. See id. at 56-60.

100. See id. at 3-4 (stressing that social classifications "express and implement" racism, sexism, and other prejudices). 
lied upon to stimulate progressive changes. The challenge appears to be to devise an effective multisite strategy that calls into question the assumptions behind current arrangements and practices.

My oversimplified description of both the structuralist and cultural domination orientation should not be read to suggest that any one theorist falls squarely within one camp and one camp only. Instead, it is most common for critical theorists to embrace aspects of both structuralist and cultural theories. A particularly good example of such a synthesis is Iris Marion Young's analysis of oppression. ${ }^{101}$ Young divides oppression into five distinctive categories: exploitation, marginalization, powerlessness, cultural imperialism, and violence and harassment. The first three categories derive from an analysis of workplace structures: "[W] ho works for whom, who does not work, and how the content of work defines one institutional position relative to others."102 For example, Young describes workers as exploited when their energies are continuously expended to augment the status of the dominants; ${ }^{103}$ as marginalized when they have no place in the system; ${ }^{104}$ and as powerless when their work is classified as nonprofessional - lacking in autonomy and respectability. ${ }^{105}$ The final two categories derive from an analysis of the impact of the dominant ideology on outsider groups: " $[\mathrm{H}]$ ow the dominant meanings of a society render the particular perspective of one's own group invisible at the same time as they stereotype one's group and mark it out as the Other."106 In its most virulent forms, stereotyping and what Young calls "cultural imperialism" can lead to systematic violence and harassment directed at such marked groups. ${ }^{107}$

Young's blend of structuralist and cultural themes yields an expanded conception of oppression capable of displacing narrower concepts of discrimination. Like many of the structuralist and cultural domination theorists described above, Young's concept of oppression as the "primary concept for naming group-related injustice"108 locates the origins of patterns of segregation and tokenism outside the oppressed group. Her five categories of op-

101. See Iris M. Young, Justice and the Politics of Difference (1990).

102. Id. at 58.

103. See id. at 48-53.

104. See id. at 53-55.

105. See id. at 56-58.

106. Id. at 58-59.

107. Id. at 62 .

108. Id. at 195. 
pression intersect at some points with legally recognized harms, notably violence, harassment, and some forms of exploitation. Not surprisingly, however, much of what Young classifies as injustice is not covered under current antidiscrimination law. The distance between Young's notion of oppression and the legal definition of discrimination represents the degree to which motivational theories predominate in the law.

\section{The Influence of Structuralist Theories in the COURTS}

In the courts, structuralist influence has been felt mainly in cases involving sexual stereotyping and sexually hostile work environments. In two major cases, Dr. Susan Fiske, ${ }^{109}$ a social psychologist of the Kanter school, has presented expert testimony designed to expand legal notions of causation and harm beyond the traditional motivational framework. Both cases involved the treatment of token women in male-dominated workplaces. In both cases the critical question was whether a woman's claim to discriminatory treatment would be judged against a comparative standard that implicitly makes men's experience the measure of fair treatment in the workplace. Hopkins $v$. Price Waterhouse ${ }^{110}$ challenged the sex bias resulting in a negative evaluation of a professional woman by her male peers. Robinson v. Jacksonville Shipyards, Inc. ${ }^{111}$ dealt with harassment of female blue-collar workers in a highly sexualized work environment. The plaintiffs won in each case, and each court cited Fiske's testimony as a factor influencing its decision. ${ }^{112}$ The structuralist orientation of Fiske's testimony, however, has not yet found its way securely into the legal doctrine. Instead, structuralist theory has been used selectively to bolster judgments for plaintiffs, without displacing the basic motivational framework.

109. I have discussed the significance of Dr. Fiske's testimony at greater length in Martha Chamallas, Feminist Constructions of Objectivity: Multiple Perspectives in Sexual and Racial Harassment Litigation, 1 TEx. J. WoMEN \& L. 95, 111-17, 133-35 (1992) [hereinafter Chamallas, Feminist Constructions of Objectivity]; and Martha Chamallas, Listening to Dr. Fiske: The Easy Case of Price Waterhouse v. Hopkins, 15 Vr. L. Rev. 89 (1990).

110. 618 F. Supp. 1109 (D.D.C. 1985), affd. in part, revd. in part, 825 F.2d 458 (D.C. Cir. 1987), affd. in part, revd. in part, 490 U.S. 228 (1989).

111. 760 F. Supp. 1486 (M.D. Fla. 1991).

112. See 490 U.S. at 235-36, 255-56; 760 F. Supp. at 1502-05, 1524-25. 


\section{A. Biased Evaluations, Causation, and Workplace Demographics: Price Waterhouse v. Hopkins}

Price Waterhouse involved the denial of partnership in a Big Eight accounting firm to a female manager who had been especially successful in bringing in clients and racking up billable hours. ${ }^{113}$ The partners voted against Anne Hopkins because they did not like her aggressive style and unladylike personal manner; a few partners were incautious enough to couch their objections in explicitly gendered comments - for example, they claimed she was too "macho" and needed "a course in charm school."114 The courts used the occasion to refine motivational analysis in those disparate treatment cases in which it is clear that the plaintiff's gender influenced the employer's decision to some degree.

In individual disparate treatment cases, a standard formulation for determining causation is the familiar "but for" test: the inquiry is whether the unfavorable treatment of the plaintiff would not have occurred "but for" her sex.115 In practice, this often means that a female plaintiff must come forward with comparative evidence of a similarly situated man who secured more favorable treatment. This showing is particularly complicated when the measures upon which employees are judged are highly subjective: whether, for example, the plaintiff gets along well with others, presents herself well to clients, or treats subordinates decently.

In Price Waterhouse, the causation question boiled down to whether Anne Hopkins was denied the partnership because of her lack of interpersonal skills or because she was a woman. Using what is known as a mixed-motivational framework, the courts tried to predict whether Hopkins's lack of social graces would have been tolerated in a man who possessed the same ability to attract clients and perform the technical aspects of the job. ${ }^{116}$ So framed, the

113. Hopkins brought in more business than any other person nominated for partner that year, she billed the most hours, and she was well regarded by clients. 825 F.2d at 462 . She was credited with winning a two-million-dollar contract with the Department of State. 490 U.S. at 233-24.

114. 490 U.S. at 235. Hopkins was advised by the partner in charge of her office that if she wanted to make partner she should "walk more femininely, talk more femininely, dress more femininely, wear make-up, have her hair styled, and wear jewelry." 490 U.S. at 235.

115. The text of Title VII prohibits discrimination "because of" an individual's race, sex, and so on. 42 U.S.C. $\$ 2000 \mathrm{e}-2(\mathrm{a})(1)$ (1988). The Court has made it clear that if a plaintiff establishes a "but-for" cause, that showing will suffice to establish liability. 490 U.S. at 240 n.6. In mixed-motivation cases, this requirement is modified to allow the plaintiff to shoulder her burden by proving that sex was a "motivating factor." 490 U.S. at 250 .

116. Using the comparative standard, the district court found that Price Waterhouse did not engage in sex-based disparate treatment. The court rejected Hopkins's assertion that the firm routinely selected male partners who were deficient in personal skills, because the court 
comparative question led to a search for the true or objective assessment of the plaintiff's personality: Was Hopkins really as obnoxious as some of the partners said she was, or were their views tainted by gender bias? Was the denial of the partnership caused by Hopkins's personality, or was it the product of the partners' prejudice against women?

Under the motivational framework, there are only two possible sources for a plaintiff's disadvantage; the harm is caused either by the plaintiff's deficiencies or by the intentionally biased attitudes of the evaluators. This dichotomous conceptualization of causation leaves little room to consider how structural features may affect the way a plaintiff's personality and performance is perceived by others in the workplace. The motivational framework does not focus directly on the dynamics of tokenism because it presumes that the structural position of male and female workers in skewed working groups is the same.

In contrast to the motivational approach, Fiske's structural analysis assumed that Hopkins's status as a token woman was of paramount importance. ${ }^{117}$ In her testimony, Fiske explained that when women are dramatically underrepresented in organizations, they are especially vulnerable to stereotyping and typecasting. ${ }^{118}$ Based on her review of the partners' comments, Fiske concluded that it was likely that Hopkins was scrutinized more closely than her male peers on nonperformance measures often associated with women. Fiske believed that once Hopkins was cast as an "iron maiden," this image might have obscured those aspects of her personality that did not fit the preconceived mold. ${ }^{119}$

Fiske's analysis cast doubt on the neutrality of the partners' view that Hopkins was overbearing and aggressive. Even those partners who thought they were being fair and objective were likely influenced by the skewed demographics of the workplace. In the structuralist account, the skewed workplace can distort the token's personality. The cause of the distortion is an imbalanced workplace, reinforced by management's failure to discourage stereotyping and typecasting.

found no sufficiently comparable case. Hopkins v. Price Waterhouse, 618 F. Supp. 1109, 1115-16 (D.D.C. 1985). The court ruled in favor of Hopkins, however, because Price Waterhouse had given weight to stereotyped comments in its evaluation of Hopkins. $618 \mathrm{~F}$. Supp. at 1120.

117. Trial Testimony of Dr. Susan Fiske, Record at 28, Price Waterhouse v. Hopkins, 490 U.S. 228 (1989) (No. 87-1167) [hereinafter Trial Testimony].

118. Id. at $26-27$.

119. Id. at 31 . 
The structuralist account is not as male-focused as the comparative standard used in motivational analysis. Structuralist theory assumes that perceptions are influenced by group status. Because of this structural difference, it is not enough to imagine how any given individual might have been treated if she had been a member of the other group, without also taking into account the difference that group membership makes. Fiske, for example, did not set out to answer the question of whether Hopkins would have fared better as a man. Even if the partners would also have objected to an overbearing and aggressive man - a highly debatable judgment Fiske would not have regarded the evaluation of Hopkins as comparable because there was no reliable way to separate Hopkins's status as a token woman from the partners' subjective assessment of her personality.

The comparative standard in motivational analysis presupposes that a judge can discover whether there are salient differences about the person being judged - besides a difference in gender that might justify treating her unfavorably. The question is approached simply as a question of fact. The structuralist account assumes that differences are socially constructed and shifts the focus from the factual inquiry about whether difference exists to an inquiry into how perceptions of difference originate and are maintained. Causation in the structuralist account is complicated by the assumption that a token's personality is shaped and sometimes distorted by her outsider status in the workplace. Under Fiske's analysis, even those partners who did not employ explicitly gendered statements to evaluate Hopkins's performance might be said to have judged her "as a woman," rather than in a truly gender-neutral fashion.

The Supreme Court in Price Waterhouse did not rely on Fiske's testimony to disavow the comparative, motivational approach but instead used it to refine the burden of proof in mixed-motivation cases. The crucial test remains whether a plaintiff would have been treated more favorably if she were a man. The burden shifts to the employer to prove lack of causation only in those instances in which the plaintiff produces direct evidence that sexism or sexual stereotyping was a "motivating factor" in the adverse decision. ${ }^{120}$

120. 490 U.S. at 250. The Civil Rights Act of 1991 modified the holding in Price Waterhouse to make the defendant liable for attorney's fees and injunctive relief, 42 U.S.C. $\S 2000 \mathrm{e}-5(\mathrm{~g})(2)(B)(\mathrm{i})$ (Supp. IV 1992), whenever the plaintiff proves that sex was a motivating factor in its decision. 42 U.S.C. $\$ 2000 \mathrm{e}-2(\mathrm{~m})$ (Supp. IV 1992). The defendant may protect itself from monetary damages - for example, back pay, compensatory, or punitive damages - and reinstatement if it proves lack of causation, that is, that the same decision 
Unlike the holding in Price Waterhouse, a doctrine fashioned along structuralist lines would not turn on whether the plaintiff could adduce some direct evidence of sex-based motivation. Instead, I interpret the structuralist approach as implying that employers should be responsible for counteracting the dynamics of tokenism if they wish to rely on subjective assessments of employee performance. I imagine that under a structuralist approach the plaintiff's prima facie case would consist of a showing of dramatic underrepresentation of the plaintiff's group, satisfactory performance by the plaintiff on objective measures, and evidence of a subjective, largely standardless selection process. In such a case, an employer would be held liable unless it could show that it had taken adequate measures to guard against stereotyping. For example, employers might avoid liability by giving decisionmaking authority to a sexually integrated group or by instituting a structured evaluation process that specified as precisely as possible the criteria to be used in making the decision.

As I envision it, to give rise to a presumption of discrimination, a structuralist approach would not require the kind of "smoking gun" evidence adduced by Hopkins. The partners at Price Waterhouse may not have been circumspect in stating their views, because the Court had only recently subjected partnership decisions to Title VII scrutiny. ${ }^{121}$ In most contemporary cases, we can expect discrimination to be more subtle. The structuralist approach assumes that dramatic gender imbalance in the workplace gives rise to gender inequity through stereotyped judgments and nonneutral evaluations, albeit couched in neutral language. If such an approach informed Title VII, employers would have a much greater incentive to hire and promote women in nontraditional jobs. It would not be sufficient merely to discourage supervisors from making explicitly sex-based comments during the evaluation process.

\section{B. Reconceiving Legal Injury: Robinson v. Jacksonville Shipyards, Inc.}

The second way structuralism has influenced Title VII litigation involves the important question of what counts as legally cognizable harm. More than other types of claims, suits for sexually hostile work environments highlight the extent to which the basic concept of injury itself is derived from the experience of the dominant

would have been made "in the absence of the impermissible factor." 42 U.S.C. $\$ 2000 \mathrm{e}-$ $5(\mathrm{~g})(2)(B)(i i)$ (Supp. IV 1992).

121. See Hishon v. King \& Spaulding, 467 U.S. 69 (1984). 
group. The type of sexual harassment first recognized by the courts - the claim for quid pro quo harassment - was easily assimilated to an injury that could also be experienced by men. Quid pro quo harassment most often takes the form of employer retaliation against a plaintiff for refusing to comply with sexual demands. ${ }^{122} \mathrm{~A}$ woman who is fired for refusing to sleep with the boss, for example, has suffered the kind of tangible economic harm that is not so different from the harm a man might suffer if he stood up to the unreasonable demands of his boss. When the claim is that of a sexually hostile environment, ${ }^{123}$ however, it is more difficult to see the injury suffered by women as analogous to what happens to men in the workplace.

Robinson ${ }^{124}$ presents a classic instance of the conflict that arises when a small number of women integrate an intensely male-dominated workplace. At the Jacksonville shipyards, sexualized images of women were so commonplace that they went unnoticed. Pornographic photographs and plaques hung on the walls, and vendors routinely distributed advertising calendars with "pinups" to employees. ${ }^{125}$ The management and the male workers believed that it was their right ${ }^{126}$ and part of their tradition to display this material, ${ }^{127}$ even though several of the pictures very explicitly demeaned women and women's bodies. ${ }^{128}$ The female employees were subjected to repeated verbal abuse and humiliation. ${ }^{129}$ The conflict escalated when plaintiff pressed her objection to the displays. She

122. The EEOC guidelines provide for liability in quid pro quo cases when "submission to such conduct is made either explicitly or implicitly a term or condition of an individual's employment [or] is used as the basis for employment decisions affecting such individual." 29 C.F.R. \& 1604.11(a)(1)-(2) (1993).

123. Offensive working environment occurs when the harassing conduct of a supervisor, coemployee, or third party - for example, a customer or client - "has the purpose or effect of unreasonably interfering with an individual's work performance or creating an intimidating, hostile, or offensive working environment." 29 C.F.R. $\$ 1604.11$ (a)(3) (1993).

124. Robinson v. Jacksonville Shipyards, Inc., 760 F. Supp. 1486 (M.D. Fla. 1991). Women constituted less than five percent of the skilled workforce at the shipyards. $760 \mathrm{~F}$. Supp. at 1493.

125. 760 F. Supp. at 1493.

126. $760 \mathrm{~F}$. Supp. at 1515.

127. Supervisors claimed that it was a "natural thing'" to have sexual pictures in a shipyard, because "nautical people always had displayed pinups and other images of nude or partially nude women, like figureheads on boats." $760 \mathrm{~F}$. Supp. at 1516.

128. For example, there was a picture of a woman's pubic area with a meat spatula pressed on it, $760 \mathrm{~F}$. Supp. at 1495, and a dart board with a drawing of a woman's breast with the nipple serving as the bull's eye, $760 \mathrm{~F}$. Supp. at 1497.

129. 760 F. Supp. at 1498-501. 
was then singled out for retaliatory harassment, and the pornographic displays intensified. ${ }^{130}$

From the vantage point of the men who dominated the workplace, the women employees brought the injury upon themselves, if it could be said that they suffered injury at all. The supervisors minimized the problem, treated the women who complained as lacking in credibility, and generally failed to prevent even repeat offenders from continuing the abuse. ${ }^{131}$

One important issue in Robinson was whether behavior that did not target a specific individual, particularly the pornographic displays, should be held to constitute a legal injury. The plaintiffs had to articulate why material that was innocuous and even pleasurable for the men was injurious to the women. Then they faced the further challenge of demonstrating to the court why their discomfort with the pornography amounted to employment discrimination.

Fiske's structuralist account of pornography's effect on the status of the women as token employees provided this important link. As in Price Waterhouse, Fiske started her analysis by explaining how the dramatic sexual imbalance at the shipyards was a precondition for a form of stereotyping known as "sex role spillover," or the tendency to regard women in terms of their sexuality and their worth as sex objects, rather than as competent co-workers. ${ }^{132}$ Fiske theorized that the presence of pornography at the worksite set in motion a process called "priming," which encouraged men to think about women in categorical, sexually objectified terms. ${ }^{133}$ Because men controlled all the positions of power at the shipyards, Fiske also noted that women were powerless to have their complaints taken seriously. ${ }^{134}$ Fiske cited research explaining that a common response to an outsider's complaint of injustice is to treat the outsider as the source of the problem, rather than to scrutinize the dominant group's behavior. ${ }^{135}$ Fiske thus was able to show how the demographics of the workplace affected the grievance process and made it unlikely that the men's behavior would easily be checked.

Fiske's structuralist account of the harassment at the Jacksonville shipyards stressed how harassment functioned as a tool of exclusion - a device to keep down the number of women in skilled

130. 760 F. Supp. at $1500-01$.

131. 760 F. Supp. at 1531-32.

132. $760 \mathrm{~F}$. Supp. at 1503.

133. 760 F. Supp. at 1503.

134. 760 F. Supp. at 1504.

135. 760 F. Supp. at 1504. 
jobs and to retard their advancement on the job. Like the scholarship of Schultz and Arriola, Fiske's testimony in Robinson uncovered the job-related consequences of a sexually hostile environment. Fiske was able to recast the injury to the plaintiffs as economic and systemic, rather than as personal and intangible. So deployed, structuralist theory described a gender-specific injury: sexual material that posed no problem for male employees could nevertheless harm the employment status of token women. In the structuralist view, the sexually oriented nature of the material could not be judged in isolation from its use in the particular work setting. The nondominant position of the women was underlined and exacerbated by the sexualized, nonprofessional ambience that pervaded the shipyards. ${ }^{136}$ Fiske described sexual harassment in structuralist terms: for her, it was both produced by and sustained by tokenism.

The district court's ruling in Robinson embraced structuralist theory to a greater degree than did the courts in Price Waterhouse. The court held that Fiske's testimony "provided a sound, credible theoretical framework from which to conclude that the presence of pictures of nude and partially nude women, sexual comments, sexual joking, and other behaviors previously described creates and contributes to a sexually hostile work environment."137 This holding in Robinson made clear that gender baiting and sexual denigration, as well as sexual propositioning, were actionable forms of sexual harassment. Moreover, the structuralist account of the harmful effects of harassment on the status of token women justified holding the employer liable, although much of the sexual material had not been displayed for the purpose of harming women and had predated the entry of women in the workplace. The court's holding made explicit what is implicit in structuralist theory: that employers have the responsibility to change the prevailing tone of the workplace to make it hospitable to newcomers. The court also accepted Fiske's testimony as a "reliable basis" for concluding that a "reasonable woman" would be harmed by the sexually hostile environment, ${ }^{138}$ thus employing structuralist theory to validate the plaintiff's subjective claim of injury.

It is still too early to predict the long-term impact of Robinson on Title VII doctrine. The case seems to have helped establish that gender baiting in male-dominated workplaces is a category of sex-

136. 760 F. Supp. at 1505.

137. 760 F. Supp. at 1505.

138. $760 \mathrm{~F}$. Supp. at 1524. 
ual harassment. ${ }^{139}$ The aspect of the case dealing with the legal status of pornography in the workplace is less secure. Critics have charged that the court's ruling violates the First Amendment and that only targeted harassment should be actionable under Title VII.140 Most importantly, beyond accepting Fiske's expert assessment in the specific case, it is not clear how Robinson alters the legal doctrine in hostile environment cases.

I would argue that a doctrine fashioned along structuralist lines should more generally incorporate Fiske's observations into the substantive law. If structuralist assumptions informed the legal concept of discrimination, it would not be necessary for plaintiff to produce an expert witness to connect the display of pornography to the existence of a sexually hostile environment, at least in those contexts in which women lacked control over the physical spaces in their workplace. If Title VII were grounded in structuralist theory, plaintiffs would be entitled to a jury instruction to the effect that the sexualization of the workplace imposes a greater burden on women than on men. The fact that the pornography was not specifically targeted at an individual female employee would not be seen as lessening its capacity to cause harm. In Robinson, the court chose to accept Fiske's theory as a validation of the particular plaintiff's injury. Fiske's theory, however, can be applied more generally to predict that the display of pornography and the toleration of sexualized behavior will have the effect of discrediting token women in male-dominated workplaces. Structuralist theory was used in Robinson to educate and persuade a particular fact finder. Its use could be extended to shape the general contours of the hostile environment claim.

\section{Cultural Domination Theory and the Victim PERSPECTIVE}

Cultural domination theory has found its way into Title VII through the debate on perspective that is currently occurring in sexual and racial harassment litigation. ${ }^{141}$ One element of proof in

139. The proposed EEOC guidelines on harassment now explicitly state that genderbased, but nonsexual, harassment violates Title VII's ban on sex discrimination. Guidelines on Harassment Based on Race, Color, Religion, Gender, National Origin, Age, or Disability, 58 Fed. Reg. 51,266, 51,267 n.2 (1993) (to be codified at 29 C.F.R. $\S 1609$ ) (proposed Oct. 1, 1993) [hereinafter EEOC Guidelines on Harassment].

140. See Kingsley R. Browne, Title VII as Censorship: Hostile-Environment Harassment and the First Amendment, 52 Oнго ST. L.J. 481 (1991).

141. For discussions of perspective, see Kathryn Abrams, Gender Discrimination and the Transformation of Workplace Norms, 42 VAND. L. REv. 1183 (1989); Naomi R. Cahn, The Looseness of Legal Language: The Reasonable Woman Standard in Theory and in Practice, 
hostile or offensive environment cases is a showing that the harassment suffered by the plaintiff is sufficiently "severe or pervasive" to alter the conditions of her employment. ${ }^{142}$ This requirement means that the plaintiff must convince the judge or jury ${ }^{143}$ that the harassment was not isolated or trivial and that it warrants federal judicial intervention.

Increasingly, courts have begun to recognize the importance of perspective in determining what counts as offensive conduct and how much offensive conduct plaintiffs will be required to endure before they have a valid claim. In a few notable cases, courts have cited feminist and critical race scholars for the proposition that the harm of discrimination ought to be judged from the perspective of those experiencing the discrimination. ${ }^{144}$ This embrace of the victim's perspective fits with cultural domination theory insofar as it provides a legal method for resisting the dominant or prevailing workplace ideologies. It also allows nondominant groups to contest the meaning and significance of everyday acts that cumulatively reinforce their position of inferiority.

The debate about perspective has been most intense in sexual harassment cases but has also surfaced in racial harassment cases. ${ }^{145}$ At one level, the issue is whether to modify the formulation of the applicable test to reflect the gender or race of the plaintiff. A burning question, for example, has been whether the severity and pervasiveness of harassment should be judged by what a reasonable person or reasonable woman would find objectionable. The deeper question, however, is how thoroughly the law will accept that work-

77 Cornell L. Rev. 1398 (1992); Martha Chamallas, Writing About Sexual Harassment: A Guide to the Literature, 4 UCLA WoMEN's L.J. 37, 49-52 (1993); and Jane L. Dolkart, Hostile Environment Harassment: Equality, Objectivity, and the Shaping of Legal Standards, 43 EMORY L.J. 151 (1994).

142. Meritor Sav. Bank v. Vinson, 477 U.S. 57, 67 (1986).

143. The Civil Rights Act of 1991 authorizes jury trials for cases of intentional discrimination in which a party seeks compensatory or punitive damages. 42 U.S.C. $\$ 1981$ a(c) (Supp. IV 1992).

144. See Ellison v. Brady, 924 F.2d 872, 878-79 (9th Cir. 1991) (citing Kathryn Abrams and Nancy Ehrenreich); Harris v. International Paper Co., 765 F. Supp. 1509, 1515-16 \& n.12 (D. Me.), modified, 765 F. Supp. 1529 (D. Me. 1991) (citing Charles Lawrence, Mari Matsuda, Derrick Bell, Patricia Williams, and Judith Scales-Trent); Lehmann v. Toys 'R' Us, Inc., 626 A.2d 445 (N.J. 1993) (citing Kathryn Abrams and Barbara Gutek); $c f$. Daniels v. Essex Group, Inc., 937 F.2d 1264, 1273 n.3 (7th Cir. 1991) (citing Mari Matsuda but retaining a reasonable person standard); Rodgers v. Western-Southern Life Ins. Co., 792 F. Supp. 628, 635 (E.D. Wis. 1992), affd., 12 F.3d 668 (7th Cir. 1993) (noting the viewpoint of reasonable black employee).

145. For a more extensive discussion of the use of modified objective standards in racial harassment cases, see Chamallas, Feminist Constructions of Objectivity, supra note 109, at 117-22, 137-42. 
place norms are often not the result of consensus or a fair balancing of interests but instead a reflection of the ability of the dominant group to shape the tone and culture of the workplace.

Prior to the Supreme Court's recent ruling in Harris v. Forklift Systems, Inc., ${ }^{146}$ the battle over perspective centered on two influential precedents representing the conservative and progressive approaches to hostile work environment litigation. On the conservative side was Rabidue $v$. Osceola Refining Co., ${ }^{147}$ a case involving a token woman who was subjected to verbal abuse by her supervisor. ${ }^{148}$ The refinery was a highly sexualized worksite in which pornography was openly displayed in common areas. ${ }^{149}$ Applying the reasonable person test, the majority of the Sixth Circuit panel found no Title VII violation. ${ }^{150}$ The court based its judgment on the belief that society condoned graphic sexual depictions in the mass media, ${ }^{151}$ including prime-time TV, and that a woman such as the plaintiff assumed the risk when she accepted a job at such a male-dominated workplace. ${ }^{152}$ Rabidue soon generated a volume of feminist commentary aimed at exposing the implicit male bias underlying the reasonable person standard and articulating the harms of the sexualized workplace from the perspective of women employees. ${ }^{153}$

On the progressive end was Ellison v. Brady, ${ }^{154}$ the most prominent decision to embrace the reasonable woman standard. Ellison involved a claim of harassment by a woman who became the target of a co-worker's romantic delusions. The plaintiff felt threatened by the pursuit because the man seemed oblivious to her lack of interest in him and ignored her requests to stop. ${ }^{155}$ The defendant argued that the pursuit was harmless and noncoercive. ${ }^{156}$ In ruling

146. 114 S. Ct. 367 (1993).

147. 805 F.2d 611 (6th Cir. 1986), cert. denied, 481 U.S. 1041 (1987).

148. One of the male supervisors 'routinely referred to women as 'whores,' 'cunt,' 'pussy,' and 'tits.' " 805 F.2d at 624 (Keith, J., dissenting).

149. 805 F.2d at $623-34$ (Keith, J., dissenting).

150. 805 F.2d at 619-20. In a dissent that later was widely cited, Judge Keith argued for application of the "reasonable woman" standard. 805 F.2d at 626 (Keith, J., dissenting).

151. 805 F.2d at 622 .

152. 805 F.2d at 620 .

153. See, e.g., Abrams, supra note 141; Nancy S. Ehrenreich, Pluralist Myths and Powerless Men: The Ideology of Reasonableness in Sexual Harassment Law, 99 YALE L.J. 1177, 1214-32 (1990); Lucinda M. Finley, A Break in the Silence: Including Women's Issues in a Torts Course, 1 YALE J.L. \& Feminism 41, 60-62 (1989).

154. 924 F.2d 872 (9th Cir. 1991).

155. 924 F.2d at 874 .

156. The district court accepted the defendant's characterization of the case and regarded the events as " "isolated and genuinely trivial." " 924 F.2d at 876. 
for the plaintiff, the appellate court drew upon feminist commentary emphasizing that women's definition of coercion might differ from men's because of women's greater exposure to sexual violence. ${ }^{157}$ The court also stressed that reasonable women have good reason to regard sexual conduct at work as a threat to maintaining their precarious hold as serious professionals. ${ }^{158}$

The Supreme Court in Harris has recently used reasonable person language to describe the appropriate test in hostile-environment cases. Without elaboration, the Court noted that "[c]onduct that is not severe or pervasive enough to create an objectively hostile or abusive work environment - an environment that a reasonable person would find hostile or abusive - is beyond Title VII's purview."159 This apparent endorsement of the reasonable person standard, however, does not mean that the Court approved of the conservative approach of Rabidue. In fact, on another point, the Court criticized Rabidue and cited Ellison approvingly. ${ }^{160}$

The perspective debate will now center on the significance and meaning of the Harris dicta. Even before Harris, the EEOC took a middle position that might well turn out to be the position of the Court. The EEOC disavowed the judgment in Rabidue about the harmlessness of pornography in the workplace ${ }^{161}$ but chose to retain the reasonable person standard. ${ }^{162}$ The agency cautioned, however, that the reasonable person standard "should not be applied in a vacuum," and that "[t]he reasonable person standard should consider the victim's perspective and not stereotyped notions of acceptable behavior."163 Most recently, the EEOC has elaborated upon what it means by application of the reasonable person standard and has expressed the view that "consideration is to be given to the perspective of individuals of the claimant's race, color, religion, gender, national origin, age, or disability."164

157. 924 F.2d at 879 n.9 (citing Abrams, supra note 141, at 1205).

158. $924 \mathrm{~F} .2 \mathrm{~d}$ at $878-79$.

159. Harris v. Forklift Sys., Inc., 114 S. Ct. 367, 370 (1993).

160. The Court rejected Rabidue's holding that Title VII plaintiffs be required to prove that they suffered severe psychological injury, adopting the Ellison view that such showing of damage was not necessary. $114 \mathrm{~S}$. Ct. at 370.

161. EEOC Policy Guidance on Sexual Harassment, Daily Lab. Rep. (BNA) No. 201, at E-4 (Oct. 18, 1988) (stating that "the Commission believes that a workplace in which sexual slurs, displays of 'girlie' pictures, and other offensive conduct abound can constitute a hostile work environment even if many people deem it to be harmless or insignificant").

162. Id.

163. Id.

164. EEOC Guidelines on Harassment, supra note 139, at 51,267. 
One interpretation of Harris and the EEOC's position is that the victim's perspective has been recognized as valid and entitled to be articulated and taken into account by the jury. What is unsettled, however, is what showing might be sufficient to convince a jury that the victim's view of events differs from the view that would be taken by a "reasonable person." It is also unclear as to whether a plaintiff is entitled to have the jury instructed that the appropriate standard is a modified one - that is, a standard expressed in terms of a reasonable person of the plaintiff's sex or race. If such a modified standard is ultimately authorized by the courts, then the apparent endorsement of the reasonable person test in Harris will ironically amount to an approval of Ellison and a repudiation of Rabidue.

It is also possible, of course, that the Court will ultimately reject the EEOC position and rule that the sex or race of the plaintiff should have no bearing on the jury's assessment of reasonableness. Harris leaves the question of perspective open. ${ }^{165}$ The Court seems committed to a concept of reasonableness or objectivity but has not yet spoken on whether reasonableness can be recast to account for perspectives of nondominant groups.

Regardless of the precise formulation of the test, the critical issue for the future will be the willingness of courts and juries to embrace the victim's perspective in assessing whether harm has occurred and the degree of harm sustained. Consideration of the victim's perspective can encourage the fact finder to look at the incidents in the workplace in light of the specific history of discrimination suffered by the nondominant group. In one recent case, ${ }^{166}$ for example, a court explained why the mention of the KKK through graffiti in the workplace would have an intimidating effect on blacks. It articulated how even one incident drawing upon this image, such as performing a KKK ritual in the workplace, might suffice to create a hostile work environment for black employees. ${ }^{167}$

Consideration of the victim's perspective also makes it more difficult to dismiss or trivialize taunts, nicknames, and epithets as pranks or jokes. In recent cases, for example, courts acknowledged the demeaning quality of the nickname Buckwheat as applied to black employees and stated that use of the term nigger, even if not directed at the plaintiff, contributes to a hostile environment be-

165. The Court stated that it was not addressing the EEOC's regulations in its opinion. Harris v. Forklift Sys., Inc., 114 S. Ct. 367, 371 (1993).

166. Daniels v. Essex Group, Inc., 937 F.2d 1264 (7th Cir. 1991).

167. 937 F.2d at 1274 n.4. 
cause it shows a lack of respect for blacks. ${ }^{168}$ This long-overdue recognition of the cruelty behind such verbal taunts may seem unremarkable. What is significant, however, is the growing acceptance of the view that this kind of everyday abuse can "corrode the entire employment relationship" 169 and ultimately reinforce the racial and sexual hierarchy in the workplace.

In cases involving forms of cultural domination other than violence and harassment, however, cultural domination theory has been less influential in the courts. When the challenge is to a specific work rule, rather than an overall claim of a hostile working environment, the courts tend to reject the victim perspective. Perhaps the most dramatic example of the continuing impact of motivational theory on the law can be seen in cases upholding Englishonly rules in the workplace. ${ }^{170}$ These cases typically forbid bilingual employees from communicating during working time with coemployees in a language other than English. 171 Employers have not been able to articulate a concrete business justification for the English-only rules and have been reduced to arguing that the use of languages other than English "unnerves" supervisors and makes monolingual employees fearful that they are being ridiculed by their colleagues. ${ }^{172}$ These are not cases in which the use of Spanish or some other foreign language would reduce efficiency or in any other way interfere with the service performed by the employees. Instead, at issue is a contest over the prevailing culture of the workplace: Does the employer have the right to preserve the Anglo character of the business even when the employees do not fit the Anglo image?

From the perspective of Latino employees who have challenged these bans, English-only rules are a manifestation of cultural domination. The plaintiffs have argued that denying them the right to speak Spanish on the job denies them a right of cultural expression

168. Rodgers v. Western-Southern Life Ins. Co., 792 F. Supp. 628, 635 (E.D. Wis. 1992), affd., 12 F.3d 668 (7th Cir. 1993); Daniels, 937 F.2d at 1264; Harris v. International Paper Co., 765 F. Supp. 1509 (D. Me.), modified, 765 F. Supp. 1529 (D. Me. 1991).

169. EEOC Guidelines on Harassment, supra note 139 , at 51,267 .

170. See, e.g., Garcia v. Spun Steak Co., 998 F.2d 1480 (9th Cir. 1993), cert. denied, 114 S. Ct. 2726 (1994); Garcia v. Gloor, 618 F.2d 264 (5th Cir. 1980), cert. denied, 449 U.S. 1113 (1981). But see Gutierrez v. Municipal Court, 838 F.2d 1031 (9th Cir. 1988) (affirming entry of a preliminary injunction against enforcement of an English-only rule), vacated as moot, 490 U.S. 1016 (1989).

171. The bans, however, generally have not covered lunch, breaks, or other personal time. See, e.g., 998 F.2d at 1483; 838 F.2d at 1037. The EEOC has taken the position that blanket prohibitions are presumptively invalid. 29 C.F.R. $\$ 1606.7$ (a) (1993).

172. See 838 F.2d at 1042. 
- a right that is accorded to English-speaking employees. ${ }^{173}$ Citing the hostile environment cases, the plaintiffs have also argued that the effect of English-only rules is to create an "atmosphere of inferiority, isolation and intimidation." 174 The claim is straightforward and antiassimilationist: to be forced to suppress one's cultural identity to suit the image of the business is insulting and demeaning.

Except for one opinion that was ultimately vacated as moot, ${ }^{175}$ plaintiffs have not succeeded in persuading the courts to view the English-only rules from the victim's perspective. Instead the courts have applied motivational analysis to uphold the rules as a reasonable exercise of management prerogative. ${ }^{176}$ The motivational argument starts from the premise that because a bilingual employee is capable of speaking English, he or she exercises a choice when deciding which language to use at work. ${ }^{177}$ The courts have determined that bilingual employees forced to speak English are not disadvantaged because they "can readily comply with the Englishonly rule and still enjoy the privilege of speaking on the job."178 In the motivational analysis, it is the employee's preference not to assimilate that causes the harm. Those persons fired for failing to conform are regarded as casualties of their own choices rather than victims of an exclusionary workplace culture.

Clearly, if the cultural domination approach were to gain greater acceptance in Title VII litigation, workplace rules such as English-only requirements would be unlawful because they primarily function as cultural markers of exclusion and hierarchy. Currently, the law permits nondominant groups a cause of action only in extreme cases in which the exclusionary behavior of supervisors and co-workers is so intolerable as to amount to pervasive and severe harassment. This limited protection against cultural domination falls short of a right to have one's cultural identity affirmed and recognized as valuable and equal. The victim's perspective is acknowledged only sporadically and has yet to secure solid footing in Title VII law.

173. 998 F.2d at $1487 ; 838$ F.2d at $1039 ; 618$ F.2d at 268.

174. 998 F.2d at $1488 ; 838$ F.2d at 1040.

175. 838 F.2d 1031.

176. See, e.g., 998 F.2d at 1487; 618 F.2d at 268-70.

177. See 998 F.2d at $1487 ; 618$ F.2d at 270.

178. 998 F.2d at 1487 ; see also 618 F.2d at 270. 


\section{POSTSCRIPT}

In the past thirty years, Title VII has become an increasingly technical and complex piece of legislation. The 1991 amendments in particular codified and refined the doctrine in both disparate treatment and disparate impact cases in an elaborate attempt to restore protections and confine judicial discretion. Significantly, however, the legislation still contains no definition of discrimination. There remains ample room for litigants, courts, and juries to shape the meaning of discrimination and workplace equality.

In this essay I have attempted to illustrate how greater acceptance of structuralist and cultural domination theories might help Title VII work to change resilient patterns of tokenism and segregation. These observations reveal no simple formula for progress, however. In the 1990s, critical theorists have confronted the pessimism and despair that results when the vast dimensions of a problem are realized. One response has been to emphasize strategy, to recognize that no single theory or set of theories will be sufficient to address "the varied, multiple and compound inequalities"179 facing nondominant groups. Each of the three orientations I have identified, including the motivational approach, can be effective strategies to challenge entrenched hierarchies in contemporary institutions and organizations. In most instances, however, I believe that structuralist and cultural domination theories more readily provide a theoretical foundation for remedying group-based harm and for developing new standards of inclusion that can diversify the workplace culture.

179. Diana Majury, Strategizing in Equality, in At tHe Boundaries of LAw: FEMINISM And Legal Theory 320, 330 (Martha A. Fineman \& Nancy S. Thomadsen eds., 1991). 